\title{
A CRITICAL ANALYSIS OF EDUCATIONAL POLICIES OF PAKISTAN
}

\author{
Mukhtyar Nabi \\ PhD Scholar, Department of Sociology, Quaid-i-Azam University Islamabad \\ Email: alimukhtyarsawal@gmail.com \\ Hifza Nazir \\ M.Phil. Scholar, Department of Sociology, Quaid-i-Azam University Islamabad \\ Email: hifzanazir555@gmail.com
}

\begin{abstract}
Education is the backbone for the development of any country in the world. It lays the foundation for social, political and economic uplift. It is widely accepted that for the prosperity of any country, quality education of their citizens is indispensable. Quality education is only possible if there are good governmental policies for its implementation. Pakistan is among the underdeveloped nations of the world and faced critical problems of education over the past many years. After the independence, from 1947 to 2017, one educational conference and eight educational policies have been implemented to upgrade the education system of the country. This paper critically examines the educational policies from 1947 to 2017 which were developed by government. It also focuses to identify the flaws in each policy which hinders the implementation and caused the reasons for its failure. The paper also suggested certain ways to forward these policies effectively in order to bring positive change in country's education.
\end{abstract}

Keywords: Educational policy; Quality education; Formation and implementation, Pakistan.

\section{INTRODUCTION}

Education is being considered as an important tool every era, but in the recent times of science and technology the importance of education can't be denied and for the better survival every society should update their education system according to the needs of the day (Dildar et al., 2016). Nowadays education is considered as an important aspect for every country in the world because without achieving global educational targets one can't mount on the ladders of progress. The global educational targets can only be achieved if there are effective educational policies for quality education. Educational policies are the collection of laws and rules that govern the operations of education system in a country. The overall national development is based on the economic development, thus, education is the way that promotes skills among citizens that can play a vital role in uplifting the nation (Zaki, 1989).

After the departure of British from the subcontinent, in 1947, Pakistan emerged as a post-colonial nation. From the day of independence to the recent past, the country has indulged in severe problems of poverty, sectarianism, insecurity and terrorism (Ahmad, 2014). There are so many reasons behind these problems like lack of tolerance and lack of general awareness, but the most important is ineffective education system that promoted illiteracy in the country. Education system of the country is ineffective because there is lack of satisfactory budget, defective examination system, political interference, poor management and supervision, directionless education, outdated curriculum, lack of research, poor quality teaching, poor physical facilities, high scale dropout of students, low enrollment, corruption, lack of uniformity, and the most important is poor governmental policies for its upbringing (Louis, 1987).

Since the inception of this country, a number of educational policies were created, and they were considered highly ambitious, but has not implemented in real sense and spirit. It is because the political leaders and other stakeholders in the policies formulation were not interested in its effective implementation and were involved in fulfillment of their own interest in the form of corruption or molding policies toward their interest side. These political leaders and stakeholders also created barriers in the way of smooth funding and proper planning for upbringing literacy ratio in the country (Zaki, 1989). 


\section{Objectives of the Study}

1. To illustrate the common commitments among different educational policies of Pakistan (19472017).

2. To instantiate changes in each educational policy.

3. To encapsulate the reasons behind failures of different educational policy.

4. To indicate various measures for effective educational policy implementation.

\section{METHODOLOGY}

The information and data existed in the paper about educational policies in Pakistan from the day of inception to present time are collected from different national and international reports and scholarly articles. The reports and articles have been evaluated thoroughly, and the required data have been presented in the form or paras and tables.

\section{Education Policies (1947-2017)}

Before the inception of Pakistan, the subcontinent was the colony of British Empire. When Pakistan came into being about 85 percent of population was illiterate and this ratio was much higher in the rural and farflung regions of the country in all the provinces. The lower rates of the illiteracy were because the British Imperialists didn't equally invest for education across the sub-continent rather they had varying polices for various nations like Hindus, Sikhs and Muslims. Although the part of subcontinent which now called India was good in literacy ratio as compared to Pakistan. Soon after the independence the government realized that nation building is only possible if there is educated and skilled manpower (Bengali, 1999). At the same year, the government convinced National Education Conference to improve country's literacy ratio. From the day of birth to 2017, one educational conference and eight (8) education policies have been made to increase the literacy ratio of the country and improve the skills of people. These education policies are;

\section{National Educational Conference 1947}

The first educational conference was held in November 1947, the founding father Quaid-e-Azam Muhammad Ali Jinnah in his inaugural address said that "there is no doubt that the future of our State will and must greatly depend upon the type of education we give to our children and the way in which we bring them up as future citizens of Pakistan." In this conference different committees were formed for the fair implementation of the conference objectives. The Primary and Secondary education committee were formed with the objective to insure the national system of education that shall be based on strong foundations of free and compulsory primary education. Pre-primary and primary stages for children were made on the basis of their ages 3-6, 6-11 respectively. The think tanks of this conference suggested that literacy ratio was much lower, and this may take 140 years to improve it. Thus, we should start adult education and campaign for its importance among the masses including females. In this policy, first five years were suggested for planning, recruitment of the teachers and training and sixth year was suggested to make 500,000 people literate. Twenty years were confined for universalization of primary education in this conference (Government of Pakistan, 1947). Beside this, two five year plans were also adopted for improvement in primary education. The first from 1951 to 57 (Government of Pakistan, Education Division, 1951) and again in 1955 another plan was adopted for next five years up to 1960 (Government of Pakistan, 1957).

\section{National Education Policy 1959}

This policy is also known as "Report of the Commission on National Education 1959" (Government of Pakistan, Ministry of Education, 1959). This policy was formulated on January $5^{\text {th }}, 1959$, during the regime of President, Muhammad Ayub Khan. In this commission, education was made compulsory up to 10 years of age and equal rights were established for both males and females. Further, this commission focused on the character building of the students, science and technical education, and establishment of new universities, research at university level, religious education at primary, middle and secondary levels, and combination of $25 \%$ internal and $75 \%$ external evaluation in examination system. 
This policy was basically commenced with a harangue on the unwanted attitude of the masses towards public duty, nation-building, government, manual work and education. It was decided that within 15 years or by 1975 , we should achieve compulsory universal enrollment of students. Further, it was observed that provision of primary education for all is a lengthy process, in order to increase literacy ratio, we should educate our adults too (Government of Pakistan, 1959). From 1959 to 1970, two five year plans were also formulated with their specific objectives. The second five-year plan started from 1960 to 1965 and the main objective was to build 4,000 new primary schools in West Pakistan and student enrollment was fixed to one million. But they only brought increase of 440,000 (Government of Pakistan, 1960).

The third five-year plan started from 1965 to 1970, which primarily focused in funds allocation to primary education and about 2,652 million rupees were allocated for said purpose. They stress on science, and technology education was given to create skilled manpower in the country (Government of Pakistan, 1965).

\section{National Education Policy 1970}

This policy is also called as the "new education policy" which was formed during the era of President Yahya Khan on $26^{\text {th }}$ March, 1970. The salient features of this policy were to emphasis on science and technology education, ideological orientation, to make decentralize the education administration and formulate national education units. In this policy, 1980 was decided to achieve the goal of compulsory, universal free primary education. Taking the data from the census, this policy claimed that in 1980, 100 million people were illiterate in Pakistan in which 90 percent were belonged to the rural regions while 10 percent were from urban areas (Government of Pakistan, 1970).

\section{National Education Policy 1972}

This policy was proposed by Prime Minister Zulfikar Ali Bhutto on $29^{\text {th }}$ March, 1972. The stress of this policy was kept on the ideology of Pakistan, equality in education and free and universal education for both males and females up to class $10^{\text {th }}$, development of personality, and formulation of science and technical education. Among the all other policies of education, this was one of the bests for the improvement in education in a real sense (Government of Pakistan, 1972).

\section{National Education Policy 1979}

This policy came into being in October 1978, during the regime of President Zia-ul-Haq and the work plan was announced in February 1979. During this policy a "National Education Conference" was organized in 1979 for reviewing the existing education system of the country. The goals which were discussed in this conference were to promote science and technical education and provision of equal opportunities for both males and females in getting education. The conference also decided that these goals can be achieved through curriculum revision, amalgamation or merging of madrassas and traditional education, and by linking technical and scientific education. Urdu language was made medium of instruction and males and females education was decided in separate environments (Government of Pakistan, 1979).

\section{National Education Policy 1992}

The plan for this policy was decided during a "National Education Conference" which held in April, 1991 in Islamabad under the chairmanship of Federal Minister of Education. Both scholars, scientists, writers, teachers, newspaper editors, and lawyers presented their proposals in preparation of this policy. After indepth conversation about different proposals, in December 1992 this policy was announced. The suggested goals for this policy were the promotion of Islamic values through education, betterment in female education, curriculum according to the demand of the day, and most important, they expanded the span of graduation and post-graduation.

\section{National Education Policy 1998-2010}

This policy was designed in January 1998 during the reign of Pervez Musharraf and it was announced in March 1998. In this policy, Quranic principals and Islamic practices were made integral part of the education system. Further, their goals were universal primary education, provision of basic educational 
facilities and opportunities to the people of the country. The basic aim of this policy was the expansion of basic education for the purpose to ensure opportunity for higher education (Government of Pakistan, 1998).

\section{National Education Policy 2009-2015}

This policy was formulated in Pakistan People's Party's (PPP) government and considered different from the previous education policies. The planning of this policy was started three years before its official announcement and different seminars and meeting were conducted to make it more effective to achieve the educational goals in a batter way. Different stakeholders took part in its designing and presented their precious suggestions. Further, this policy focused on early child education (ECE) which was historically ignored in the other policies. It was suggested that children from age 3 to 5 should be taught in at least $1^{\text {st }}$ great lessons and make them able of study before starting their primary education. In this policy, non-formal education was also made importantly for adults to improve the literacy of the country. The stress on quality education was also one of the primary aims of this policy. Regarding quality education, this policy argued that six pillars can play their prominent role i.e. teacher, curriculum, textbooks, assessment, learning environment, and make education important in their practical life.

\section{National Education Policy 2017-2025}

This policy was implemented during the regime of Pakistan Muslim League Nawaz (PMLN) and announced by the Federal Minister of Pakistan. The main focus of this policy was to increase the number of public-sector colleges and universities in the country. They focused on virtual education and suggested to increase the number of virtual universities. It was also suggested that we should facilitate the privatesector universities in their establishment. More sub-campus of colleges and universities should be opened to make better access for the students at their door steps. In this policy special focus was paid on the special education, and it was decided that by 2025 about $50 \%$ of special children shall be enrolled in special education sector. Further, this policy clearly announced 5\% separate education budget for special education in the country.

\section{Flows in the Implantation of Education Policies in Pakistan (1947-2017)}

In general, there were a lot of issues which created hindrances in achieving goals in each education policy in Pakistan. These issues are poor communication, weak administration, poor policy evaluation, financial gap and irregularity, attitude and nature of the public servant, incompetent bureaucratic structure, lack of political will, poor leadership and corruption (Ahmad et al., 2012). Rashid (2004) stated that all education policies were plagued by poor communication. There was rare support and ownership from stakeholders' side and their commitment was also meaningless. In all policies, the collaboration, support, and cooperation were somehow missing among all implementers, and their approaches toward the completion of policy goals was less accurate and less consistence.

Strong administration plays a pivotal role in any policy's implementation phase. According to Government of Pakistan (1998) failures in all educational policies of Pakistan were weak and imperfect implementation mechanism, poor training of implementers, low political commitment, and absence of incentives for proceeding the policy implementation. All the stakeholders who took part in policy implementation was not interested in its evaluation in real sense. They only proceeded with their work, but didn't scrutinized their previous work. In this connection, Bukhari (1995) argued for the better implementation of policy, not only we need information, but we need adequate information that bring progress in implementation of policy process.

Further, in all education policy, the financial gap and irregularities were found as a major problem. In this regard a reported was presented by UNESCO in 2005 in which they showed that inadequate financial resources are one the main hindrances in education policy implementation in Pakistan. For the achievement of educational goals in each policy, we need enough financial support, buildings, and equipment because with these things we can't overcome any policy for education properly (Siddiqui, 1993). The bureaucratic structure or red tapism was also considered as hindrance in effective implementation of these policies. Half success of the policy depends on its making or formulation that how smooth it is designed. If policy is 
formulated by taking all advantages and disadvantages in mind, then more chances are there for its effective implementation. Unfortunately, in Pakistan all education policies are formulated by bureaucrats with less will and incompetent skills (Shahid, 2003).

Any policy that may be for education or for other things requires fair dealing, and if there is corruption then we can't achieve the aims of that policy. For the effective implementation of policy, the stakeholder sacrifices their time and resource, but unfortunately in all education policies of Pakistan the stakeholders were interested to achieve their own benefits. All the policies were full of corruption, and everyone took their part to accumulate resource for themselves instead of for the effective implementation of the policy (Riaz, 1998).

\section{Reasons behind Failure of Education Policy (1947-2017)}

After the inception, the founding father inaugurated step in the form of national educational Conference to improve the country's literacy ratio, but the objectives of the conference were not achieved because this was a new country and population was more than the available resources. Further, immigration was also started which was extra burden on the country. Besides this, for effective policy implementation, strong and dedicated administration was indispensable but due to newly emergence, the administrative setup was very weak and was not in a better position to handle such issues. Thus, this policy was failed to achieve its goals.

\section{National Education Policy 1959}

Although this policy was designed and implemented a decade later after the independence, but still the country was very weak in terms of resources availability. Further, the position of the country was also very weak because the command of the government was in the hand of military personnel and environment of the country was not smooth for effective education policy implementation, due to which unfortunately the set objectives of the policy were not achieved.

\section{National Education Policy 1970}

This policy was also not implemented mainly due to the separation of East Pakistan, fewer resources and economically weak conditions of the country lead to non-achievement of the policy goals in the given time frame.

\section{National Education Policy 1972}

This policy was designed at the time when two wars were fought between Pakistan and India and country's situation was not easy to implement any policy in more effective ways. Further, country's economy was also very low, and this was a big hindrance in achieving the goals of this education policy.

\section{National Education Policy 1979}

As we can see that lack of financial resources was the big hindrance in the way of effective education policy implementation in the previous years, thus, this policy was also coupled with same issues. Beside this, the planning of government was also not up to the mark that can easily fulfill the objectives of this policy.

\section{National Education Policy 1992}

In the ineffective implementation of this policy, the political scenario of the country played important role. This policy was designed during PPP's government, but the government of Benazir Bhutto was ended by then President Ghulam Ishaq Khan that created crucial circumstances for the stakeholders of education policy to implement it properly.

\section{National Education Policy 1998-2010}

Although this policy was designed by President Pervez Musharraf in proper way, but due to unavailability of trained teachers this policy was unable to entertain the expectations of stakeholders. This policy was implemented for achieving quality education, but the untrained teachers became a major hindrance in its way. 
Table 1. A Comparison of the Major Components of Different Educational Policies

\begin{tabular}{|c|c|c|c|c|}
\hline S. No & $\begin{array}{l}\text { National } \\
\text { Education } \\
\text { Policy }\end{array}$ & Regime & Major Components of the Policy & $\begin{array}{l}\text { Major Reasons Behind } \\
\text { Failure of Policy }\end{array}$ \\
\hline 1 & 1959 & Ayub Khan & $\begin{array}{l}\text { Equal rights for boys and girls, character } \\
\text { building, establishment of universities, } \\
\text { combination of internal ( } 25 \%) \text { and } \\
\text { external ( } 75 \%) \text { evaluation in examination } \\
\text { system, introduction of the religious } \\
\text { education at middle (compulsory), } \\
\text { secondary (optional), and university } \\
\text { level. }\end{array}$ & $\begin{array}{l}\text { Limited resources and } \\
\text { weak position of the } \\
\text { state. }\end{array}$ \\
\hline 2 & 1970 & Yahya Khan & $\begin{array}{l}\text { Ideological orientation, science and } \\
\text { technology education, decentralization of } \\
\text { education administration, and } \\
\text { formulation of national education. }\end{array}$ & $\begin{array}{l}\text { Limited resources and } \\
\text { weak position of the } \\
\text { state as well as the } \\
\text { separation of East } \\
\text { Pakistan. }\end{array}$ \\
\hline 3 & 1972 & $\begin{array}{l}\text { Zulfikar Ali } \\
\text { Bhutto }\end{array}$ & $\begin{array}{l}\text { Promotion of ideology of Pakistan, } \\
\text { equality in education, personality } \\
\text { development, technical and science } \\
\text { education, free and universal education } \\
\text { up to } 10^{\text {th }} \text { class. }\end{array}$ & $\begin{array}{l}\text { Low economic rate, and } \\
\text { wars between Pakistan } \\
\text { and India. }\end{array}$ \\
\hline 4 & 1979 & Zia-ul-Haq & $\begin{array}{l}\text { Curriculum revision, merging madrassas } \\
\text { and traditional education, Urdu as a } \\
\text { medium of instruction, linked scientific } \\
\text { and technical education, separate setup } \\
\text { for males and females. }\end{array}$ & $\begin{array}{l}\text { Lack of planning and } \\
\text { financial resources. }\end{array}$ \\
\hline 5 & 1992 & $\begin{array}{l}\text { PML(N) } \\
\text { Government }\end{array}$ & $\begin{array}{l}\text { Promotion of Islamic values through } \\
\text { education, improvement in women } \\
\text { education, demand oriented curriculum, } \\
\text { expanding span of graduation and post- } \\
\text { graduation. }\end{array}$ & $\begin{array}{l}\text { Change in political } \\
\text { scenario of the country. }\end{array}$ \\
\hline 6 & 1998-2010 & $\begin{array}{l}\text { Pervez } \\
\text { Musharraf }\end{array}$ & $\begin{array}{l}\text { Quranic principles and Islamic practices } \\
\text { were made as integral part of education } \\
\text { system, universal primary education, } \\
\text { meet the basic educational needs for } \\
\text { everyone, and expand the basic education } \\
\text { to ensure opportunities of higher studies. }\end{array}$ & $\begin{array}{l}\text { Untrained teachers and } \\
\text { lack of quality } \\
\text { education. }\end{array}$ \\
\hline 7 & 2009-2015 & $\begin{array}{l}\text { PPP's } \\
\text { Government }\end{array}$ & $\begin{array}{l}\text { Focus on curriculum, textbooks, } \\
\text { assessment, teachers, } \\
\text { environment in institutions, relevant of } \\
\text { education to practical life/ labour market. }\end{array}$ & $\begin{array}{l}\text { Long wish list } \\
\text { (allocation for } \\
\text { education will be } 7 \% \text { of } \\
\text { GDP by 2015). Lesser } \\
\text { budget allocations, } \\
\text { administrative hurdles. }\end{array}$ \\
\hline 8 & 2017-2025 & $\begin{array}{l}\text { PML(N) } \\
\text { Government }\end{array}$ & $\begin{array}{l}\text { To build more colleges and university, } \\
\text { give importance to special education and } \\
\text { allow separate education budget for them. }\end{array}$ & $\begin{array}{l}\text { Lesser budget } \\
\text { allocations, } \\
\text { administrative issues. }\end{array}$ \\
\hline
\end{tabular}




\section{National Education Policy 2009-2015}

Focusing on the objectives of this policy we can say that it was just a long list of wishes. It is because, in this policy it was decided that the government will allocate 7\% of GDP by 2015 which was an utter wish. Their focus was also to make same curriculum for public and private schools but this wish was also not achieved during this time.

\section{National Education Policy 2017-2025}

Although the situation is becoming worst for the achievement of the already set goals in this policy because the current weak economic and political conditions of the country it is beyond possibility to achieve these goals. Further, the spread of Covid-19 pandemic has also created severe repercussion on each policy of the country, including education and it can make more difficult to achieve the targets set in it. Still this policy is under process and striving to achieve its goals.

\section{Table 2. Similarities in the Components of Different Policies (1947-2017)}

\begin{tabular}{|c|c|c|}
\hline S. No & Policies & Components \\
\hline 1 & 1972,2010 & $\begin{array}{l}\text { Free and compulsory education; free and universal education up to } 10^{\text {th }} \text { class; } \\
\text { universal primary education; and meet the basic educational needs to } \\
\text { everyone. }\end{array}$ \\
\hline 2 & $\begin{array}{l}\text { 1959, 1972, } \\
1979,1992\end{array}$ & $\begin{array}{l}\text { Equal rights for boys and girls; equality in education; separate setup for males } \\
\text { and females; and improvement in women education. }\end{array}$ \\
\hline 3 & $\begin{array}{l}\text { 1959, 1972, } \\
\text { 2009-2015 }\end{array}$ & $\begin{array}{l}\text { Character building; personality development; and education for practical life/ } \\
\text { labour market. }\end{array}$ \\
\hline 4 & $\begin{array}{l}\text { 1959, 1992, } \\
\text { 1998-2010 }\end{array}$ & $\begin{array}{l}\text { Introduction of religious education at middle (compulsory) secondary } \\
\text { (optional), and university levels; promotion of Islamic values through } \\
\text { education; and Quranic principles and Islamic practices on integral part of } \\
\text { education system. }\end{array}$ \\
\hline 5 & 1970,1972 & Ideological orientation; and promotion of ideology of Pakistan. \\
\hline 6 & 1970, 1972 & Science and technology education: linking technical and scientific education. \\
\hline 7 & $\begin{array}{l}\text { 1979, 1992, } \\
\text { 2009-2015 }\end{array}$ & Curriculum revision; demand oriented curriculum; and focus on curriculum. \\
\hline 8 & $\begin{array}{l}1992,1998- \\
2010\end{array}$ & $\begin{array}{l}\text { Expanding span of graduation and post-graduation; and expanding the basic } \\
\text { education to ensure opportunities of higher studies. }\end{array}$ \\
\hline
\end{tabular}

\section{CONCLUSION}

Education is a path toward the development, and a country can reach to the peak of its development through well-directed education system. When Pakistan came into being, the literacy ratio was much lower as compared to India. Thus, in order to improve it, the country had to think out of the box by implementing its first five-year plan which unfortunately didn't go well. The first national education conference was held aimed to improve the enrollment of the children at primary school levels by because of the financial and administrative issues it was unable to achieve such goals. Although the aims of this conference were bright, but the situation of the country was worst because of huge immigration and less availability of resources. So, objectives of this conference remained unachieved. Then after, various education policies were designed i.e. 1959, 1970, 1972, 1979, 1992, 1998, and 2009-2015 for improvement in education and make it quality based but in each era the situation was not pleasant as there were some untoward issues that made the implementations impossible. The stakeholders and government figures were seemingly not interested in its effective implementation and their aim was just to fulfill their own interests.

In the light of literature review, it is now clear that lack of direction, poor relationship among institutions and community, inconsistency, corruption, weak leadership, commitment gaps between policy formulation and implementation were among the major causes behind failure. These policies formulators and implementers were also very weak in their work because of lack of funds and lesser trained staff. The 
most important point in the ineffective implementation of all education policies was the ignorance of teachers. In all policies, teachers were ignored, and they just focused on the enrollment of students, allocation of funds, building of schools, colleges and universities and so on. In order to implement education policy in an effective way, the government and other stakeholder should focus on national interests instead of self-interests and they should cover all the aspects that are linked with the policy and can play their precious roles in its effective implementation.

\section{SUGGESTIONS FOR EFFECTIVE IMPLEMENTATION}

After focusing on the available secondary data in the form of government and international organizations,' reports this study has made some suggestions for the effective education policy implementation.

1. As we know that policy is the process that helps any system to solve problems. Education policy is the process that aims to solve problems of education. Unfortunately, in Pakistan the formulation of this policy is in the hand of bureaucrats and those people who are not well-trained to design it in a more efficient way. So, the government should need to involve the well-trained people in the policy formulation. More importantly, the government should also give this responsibility in the hands of educationist and experts in education because they know the pros and cons of each aspect of education.

2. There should be proper way of sharing productive information regarding education policy among both policy formulators and implementers because most of the policies failed due to poor communication among the stakeholders.

3. There should be strong evaluation (concurrent and periodic) from the stakeholder and government's side that policy remains well-directed. If they only focus on their own interests and forget to formulation a better policy or a weak implementation, then the goals can't be achieved in a given time frame.

4. In each policy, the corruption and personal interests of stakeholders was found. So, there should be a strong accountability system which focus on such issues which become a major hindrance in the policy formulation and implementation.

5. Our country is economically weak and has limited resources that required for effective policy implementation. Thus, the government should need to make effective planning regarding utilization of these scare resources and to achieve the policy goals with these limited resources.

6. The government should need to create awareness among the people regarding policy goals and insist the masses to help them in a better implementation of the policy to achieve the desired results.

\section{REFERENCES}

Ahmad, I. (2014). Critical analysis of the problems of education in Pakistan: Possible solutions. International Journal of Evaluation and Research in Education, 3(2), 79-84.

Ahmad, I., Rauf, M. Imdadullah, \& Zeb, A. (2012). Implementation gaps in educational policies of Pakistan: Critical analysis of problems and way forward. International Journal of Humanities and Social Science, 2(21), 240-245.

Bengali, K. (1999). History of educational policy making and planning in Pakistan. Islamabad: Sustainable Development Policy Institute.

Bukhari, M.A. (1995). Plan implementation and management (Unit 16). Islamabad: Allama Iqbal Open University, pp. 113-118.

Dildar S.M., Saif, N.N., \& Naz A. (2016). Review of educational policies of Pakistan: Planning and implication flows. IC5 Es- Proceedings, 25-26 October, 2016 University of Sargodha/Pakistan

Government of Pakistan. (1947). Proceedings of the Pakistan educational conference. Islamabad: Ministry of the Interior, Education Division.

Government of Pakistan. (1951). Proceedings of the educational conference. Islamabad: Education Division.

Government of Pakistan. (1957). The first five year plan: 1955-60. Islamabad: Planning Commission. 
Government of Pakistan. (1959). Report of the commission on national education. Islamabad: Ministry of Education.

Government of Pakistan. (1960). Second five year plan: 1960-65. Islamabad: Planning Commission. Government of Pakistan. (1965). Third five year plan: 1965-70. Islamabad: Planning Commission.

Government of Pakistan. (1970). The new education policy. Islamabad: Ministry of Education and Scientific Research.

Government of Pakistan. (1972). The education policy. Islamabad: Ministry of Education.

Government of Pakistan. (1979). National education policy and implementation programme. Islamabad: Ministry of Education.

Government of Pakistan. (1998). National education policy 1998-2010. Islamabad: Ministry of Education. Government of Pakistan. (1998). National education policy: 1998-2010. Islamabad: Ministry of Education. Louis, D.H. (1987). The crises of education in Pakistan. Lahore, Vanguard Books.

Rashid, K. (2004). Education. Lahore: Carvan Book House.

Riaz, R. (1998). Introduction to education. Lahore: Ehtasham Publishers.

Shahid, S.M. (2003). Elementary education in Pakistan. Lahore: Majeed Book Depot.

Siddique, A.S. (1993). Process of educational planning in Pakistan (Unit 2). Islamabad: Allama Iqbal Open University.

UNESCO. (2005). Decentralization in education: National policies and practices. Education policies and strategies 7. Paris: United Nations Educational, Scientific and Cultural Organization.

Zaki, W.M. (1989). Evaluation of education plans and projects. Islamabad: National Book Foundation. 